\title{
Reinforced concrete slabs subjected to thermal loads
}

\author{
F.J. Vecchio, N. Agostino, and B. Angelakos \\ Department of Civil Engineering, University of Toronto, Toronto, ON MSS IA4, Canada \\ Received October 14, 1992 \\ Revised manuscript accepted January 22, 1993
}

\begin{abstract}
Eight large-scale reinforced concrete slab specimens were tested under combined thermal and mechanical load conditions. The specimens varied in the amount and orientation of the in-plane reinforcement provided. A three-phase loading regime was used to investigate thermal gradient effects at service and ultimate load conditions. The slabs experienced significant levels of stressing and cracking as a result of restrained thermal deformations. However, reductions in stiff ness due to cracking and thermal creep caused rapid decays in the restraint forces developed. At ultimate load conditions, thermal load effects were minimal. Nonlinear finite element analysis procedures were used to investigate the theoretical response of the test slabs. Fairly accurate simulations of the specimens' behaviour were obtained. Important to achieving accurate results were the consideration of tension stiffening effects and out-of-plane shear behaviour.
\end{abstract}

Key words: analysis, cracking, finite elements, plates, reinforced concrete, slabs, temperature, tests, thermal gradients.

Huit échantillons à grande échelle de dalle de béton armé ont été soumis à des charges thermiques et mécaniques combinées. La quantité et l'orientation des armatures au plan d'ossature porteuse variaient d'un échantillon à l'autre. Un régime de chargement en trois phases a été utilisé pour analyser les effets des gradients thermiques en présence de conditions de charge ultime et réelle. Les dalles ont subi d'importants niveaux de contrainte et de fissuration en raison de déformations thermiques produites par l'encastrement. Cependant, des réductions de la rigidité causées par la fissuration et le fluage thermique ont provoqué une dégradation rapide des forces contraignantes développées. En présence de conditions de charge ultime, les effets des charges thermiques étaient minimes. Des méthodes d'analyse non linéaire des éléments finis ont été utilisées pour étudier la réponse théorique des dalles d'essai. Des simulations relativement précises du comportement des échantillons ont été réalisées. Afin d'obtenir des résultats précis, il a fallu tenir compte des effets du raidissement de tension et du cisaillement hors plan.

Mots clés : analyse, fissuration, éléments finis, plaques, béton armé, dalle, température, tests, gradients thermiques.

[Traduit par la rédaction]

Can. J. Civ. Eng. 20, 741-753 (1993)

\section{Introduction}

Reinforced concrete structures are commonly exposed to thermal loads as the result of the design function of the structure, ambient conditions, heat of hydration, or exposure to fire. Thermal loads can give rise to significant levels of stress, distortion, and damage as a consequence of nonlinear temperature and strain profiles (producing "primary" thermal stresses), and restrained structural deformation (producing "secondary" or "continuity" thermal stresses) (Priestley 1981). Typically, the latter type of stress is of greater magnitude and more concern. Types of structures often exposed to thermal loads include nuclear containment structures, offshore structures, and bridges.

Extensive research has been conducted in regards to thermal stress effects in concrete frame-type structures (e.g., Priestley 1981; ACI Committee 435 1985; Vecchio and Sato 1990). The behaviour and design of such structures, for load conditions including thermal loads, is thus fairly well understood. Analysis procedures developed to model the behaviour of thermally loaded frames have been shown to provide reasonably accurate results (e.g., Thurston et al. 1980; Vecchio 1987).

Considerably less work has been undertaken with regards to the analysis and design of concrete shell-type structures under thermal loading conditions. The design recommendations made by ACI Committee 349 (1980) are cursory and do not accurately represent behaviour. The analysis procedures available, typically in the form of finite element

NOTE: Written discussion of this paper is welcomed and will be received by the Editor until February 28, 1994 (address inside front cover).

Printed in Canada / Imprimé au Canada methods, often do not adequately represent post-cracking concrete tensile stress effects, which are critical to the analysis of any deformation-controlled load effect.

A two-part experimental program was undertaken to investigate thermal load effects in shell-type structures. The first phase of the research program involved simple slab specimens subjected to various combinations of thermal and mechanical loads. The second phase was to involve more complex rectangular and cylindrical type structures subjected to internal heating. Concurrent work was undertaken to develop corresponding nonlinear finite element analysis capabilities; details regarding the formulations developed are presented elsewhere (Polak and Vecchio 1993). The results of the test program were to be used to corroborate the analysis procedure.

This paper represents the details and results of the first phase of the experimental program. As well, the ability of the nonlinear finite element procedures to accurately represent behaviour is examined.

\section{Specimen details}

The test slabs were $2800 \mathrm{~mm}$ square with a thickness of $150 \mathrm{~mm}$. Two layers of in-plane reinforcement were provided in each of two orthogonal directions. The slabs were designed to be simply supported at the corners and subjected to concentrated mechanical loads applied at the centre. Accordingly, bearing plates at the corners and an anchorage plate at the centre were provided. In these regions, out-of-plane reinforcement was used to increase the slabs' shear resistance. Details of the specimen construction are given in Fig. 1 and Table 1. 


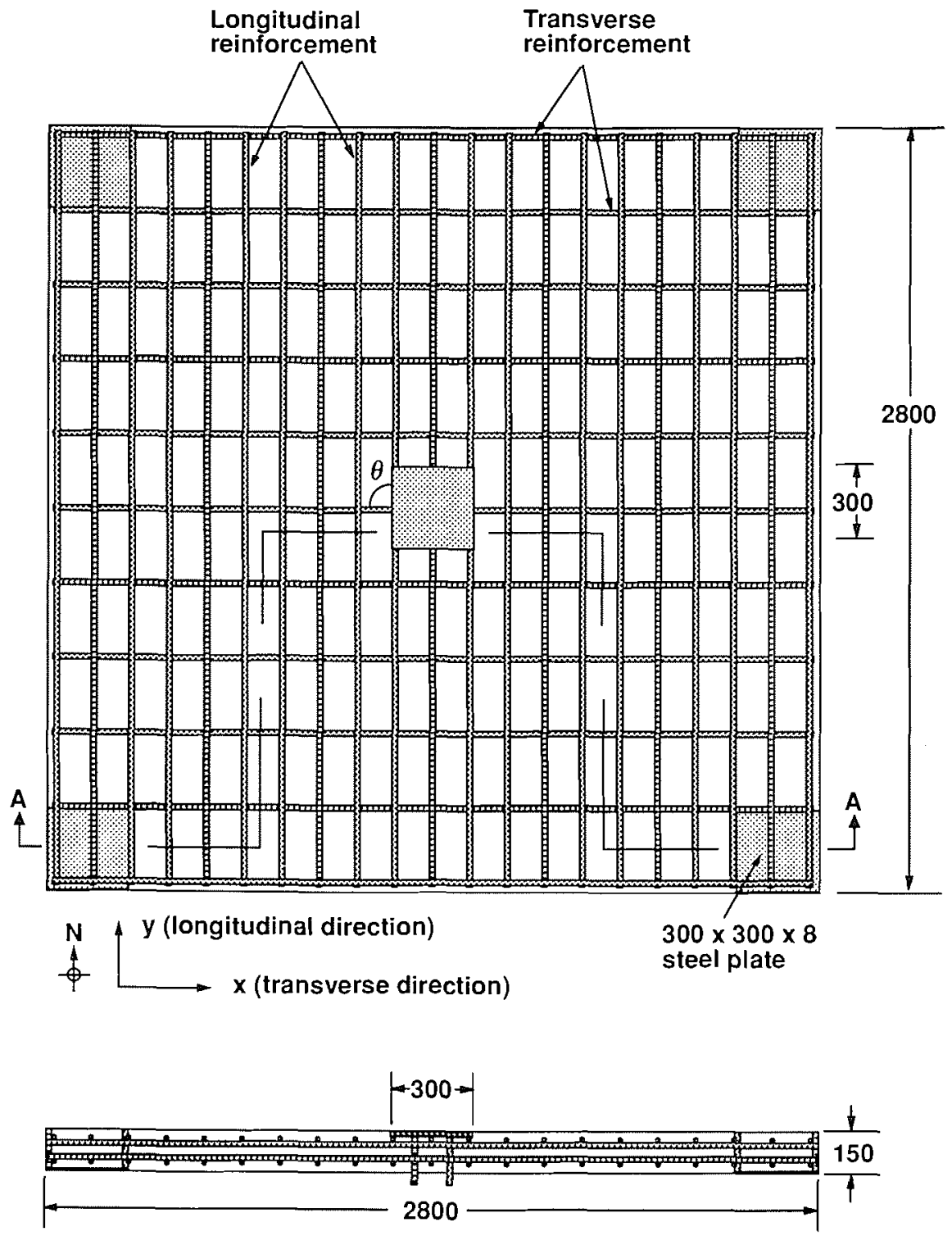

FIG. 1. Details of test slabs.

The pattern and the amount of in-plane reinforcement provided were the main test variables. In one set of specimens, the percentages of reinforcement in the strong and weak directions were kept constant at $1.50 \%$ and $0.75 \%$, respectively, while reinforcement orientation with respect to the slab sides was varied between $0^{\circ}$ and $45^{\circ}$. In a second set of specimens, the reinforcement orientation was kept constant at $0^{\circ}$ while the percentages of reinforcement were varied. The reinforcement details are also shown in Fig. 1.

The concrete used to construct the slabs was ready-mixed, specified at $30 \mathrm{MPa}$ strength with $10 \mathrm{~mm}$ crushed limestone aggregate and $70 \mathrm{~mm}$ slump. The mechanical properties of the concrete, at the time of testing (typically, 4-6 months after casting), were determined from standard cylinders and prisms. The results are tabulated in Table $2 a$. (Note: The coefficients of thermal expansion were determined from dried, sealed prisms.) A typical compressive stress-strain response curve for the concrete is given in Fig. $2 a$.

The in-plane reinforcement used consisted of No. $15 \mathrm{M}$ and (or) No. 20M deformed bars; No. 10M bars were used for shear reinforcement. The mechanical properties deter- mined from coupons are given in Table $2 b$. Typical stressstrain curves are shown in Fig. $2 b$.

The test slabs were extensively instrumented. Strain gauges were applied to the reinforcement in several locations on each face and in each direction. T-type thermocouples were applied at all strain gauge locations (for temperature corrections), and at regular intervals along the top and bottom surfaces of the slabs. As well, for determining nonlinear temperature profiles through the slab thickness, prisms containing thermocouples at a $20 \mathrm{~mm}$ spacing were placed through the thickness at two locations. Slab deflections were monitored with LVDTs placed beneath the slab, and load cells were placed at the four corner supports. All instruments were continuously monitored using computer-controlled data acquisition systems.

\section{Loading conditions}

The test specimens were subjected to three separate loading regimes, involving combinations of thermal and mechanical loads. 
TABLE 1. Specimen reinforcement details

\begin{tabular}{|c|c|c|c|c|c|c|c|c|}
\hline \multirow[b]{2}{*}{ Specimen } & \multicolumn{3}{|c|}{$X$-reinforcement } & \multicolumn{3}{|c|}{$Y$-reinforcement } & \multirow[b]{2}{*}{$\begin{array}{c}\theta \\
(\mathrm{deg})\end{array}$} & \multirow[b]{2}{*}{$\begin{array}{l}\text { Reinforcement } \\
\text { pattern }\end{array}$} \\
\hline & $\begin{array}{c}\rho_{x}^{*} \\
(\%)\end{array}$ & $\begin{array}{l}\text { Bar } \\
\text { type }\end{array}$ & $\begin{array}{l}\text { Spacing } \\
(\mathrm{mm})\end{array}$ & $\begin{array}{c}\rho_{y}^{*} \\
(\%)\end{array}$ & $\begin{array}{l}\text { Bar } \\
\text { type }\end{array}$ & $\begin{array}{l}\text { Spacing } \\
(\mathrm{mm})\end{array}$ & & \\
\hline TS2 & 0.75 & $20 \mathrm{M}$ & 260 & 1.50 & $20 \mathrm{M}$ & 130 & 0 & \\
\hline TS3 & 0.75 & $20 \mathrm{M}$ & 260 & 1.50 & $20 \mathrm{M}$ & 130 & 15 & $x+\frac{1}{1}$ \\
\hline TS4 & 0.75 & $20 \mathrm{M}$ & 260 & 1.50 & $20 \mathrm{M}$ & 130 & 30 & 我 \\
\hline TS5 & 0.75 & $20 \mathrm{M}$ & 260 & 1.50 & $20 \mathrm{M}$ & 130 & 45 & \\
\hline TS6 & 1.50 & $20 \mathrm{M}$ & 130 & 1.50 & $20 \mathrm{M}$ & 130 & 0 & ${ }^{y}{ }^{\prime}$ \\
\hline TS7 & 1.00 & $20 \mathrm{M}$ & 200 & 1.50 & $20 \mathrm{M}$ & 130 & 0 & ${ }^{{ }^{y}} \mathrm{f}^{\prime}$ \\
\hline TS8 & 0.40 & $15 \mathrm{M}$ & 330 & 1.50 & $20 \mathrm{M}$ & 130 & 0 & $x$ \\
\hline TS9 & 0.40 & $15 \mathrm{M}$ & 330 & 0.75 & $20 \mathrm{M}$ & 260 & 0 & ${ }^{y}$ \\
\hline
\end{tabular}

*Per layer.

Thermal loads were applied to the top surfaces of the test slabs through the use of a heating chamber. The heating chamber consisted of 11 flexible silicone bladders contained within an insulated shell (see Fig. 3). The bladders were supported by hanger assemblies which allowed them to remain in contact with the top surface of the slab as it underwent deformations. Water heated in a $1000 \mathrm{~L}$ remote reservoir, using two $30 \mathrm{~kW}$ immersed heaters, was continually circulated through the bladders. Individual flow valves on each bladder, and precise temperature controls on the heater, permitted fairly uniform heating of the slab surface. The heating chamber covered the entire top surface area of the slab except for a $150 \mathrm{~mm}$ wide band around the perimeter. Large fans positioned around the test specimens were effective in keeping the bottom surfaces at close to room temperature. Hence, the "thermal gradient" loads applied refer to the differences between the top and bottom surface temperatures.

Mechanical loads were applied using a $1000 \mathrm{kN}$ capacity servo-controlled actuator. The actuator attached to the anchor plate at the centre of the bottom surface of the slab, and was connected at the other end to the laboratory strongfloor. The test setup is illustrated in Fig. 3.

The first phase of testing involved applying thermal loads to the unrestrained slabs (i.e., the actuator at the centre was not attached). The objectives were to investigate transient thermal gradient (i.e., nonlinear temperature profile) and primary thermal stress effects. As well, for analysis corroboration purposes, the magnitude of slab deflection for a given level of thermal gradient was required. The thermal loading consisted of a top surface temperature increase of about $40^{\circ} \mathrm{C}$, maintained for a period of 6 hours. It was anticipated 
TABLE $2 a$. Material properties - concrete

\begin{tabular}{cccccc}
\hline Specimen & $\begin{array}{c}f_{\mathrm{c}}^{\prime} \\
(\mathrm{MPa})\end{array}$ & $\begin{array}{c}f_{!}^{\prime} \\
(\mathrm{MPa})\end{array}$ & $\begin{array}{c}\varepsilon_{\mathrm{c}}^{\prime} \\
\left(\times 10^{-3}\right)\end{array}$ & $\begin{array}{c}E_{\mathrm{c}} \\
(\mathrm{MPa})\end{array}$ & $\begin{array}{c}\alpha_{\mathrm{s}} \\
\left(\times 10^{-6} /{ }^{\circ} \mathrm{C}\right)\end{array}$ \\
\hline TS2 & 43.2 & 2.35 & 2.44 & 35400 & 10.5 \\
TS3 & 39.4 & 2.25 & 2.41 & 32700 & 11.3 \\
TS4 & 30.7 & 1.90 & 2.59 & 23700 & 10.7 \\
TS5 & 38.9 & 2.29 & 2.19 & 35500 & 11.2 \\
TS6 & 39.9 & 1.90 & 2.39 & 33400 & 10.3 \\
TS7 & 41.5 & 2.52 & 2.48 & 33500 & 11.8 \\
TS8 & 37.1 & 2.01 & 2.41 & 30800 & 10.6 \\
TS9 & 44.2 & 2.54 & 2.47 & 35800 & 10.8 \\
\hline
\end{tabular}

TABLE $2 b$. Material properties - reinforcement

\begin{tabular}{lcccccccc}
\hline \hline Bar type & $\begin{array}{c}\phi \\
(\mathrm{mm})\end{array}$ & $\begin{array}{c}A_{\mathrm{s}} \\
\left(\mathrm{mm}^{2}\right)\end{array}$ & $\begin{array}{c}f_{\mathrm{y}} \\
(\mathrm{MPa})\end{array}$ & $\begin{array}{c}f_{\mathrm{u}} \\
(\mathrm{MPa})\end{array}$ & $\begin{array}{c}E_{\mathrm{s}} \\
(\mathrm{MPa})\end{array}$ & $\begin{array}{c}E_{\mathrm{sh}} \\
(\mathrm{MPa})\end{array}$ & $\begin{array}{c}\boldsymbol{E}_{\mathrm{sh}} \\
\left(\times 10^{-3}\right)\end{array}$ & $\left(\times 10^{-6} /{ }^{\circ} \mathrm{C}\right)$ \\
\hline No. 10M & 10 & 100 & 452 & 621 & 200000 & - & - & 10.0 \\
No. 15M & 15 & 200 & 484 & 646 & 200000 & 3250 & 22.06 & 10.0 \\
No. 20M & 20 & 300 & 390 & 530 & 200000 & 2150 & 14.25 & 10.0 \\
\hline
\end{tabular}

(a)

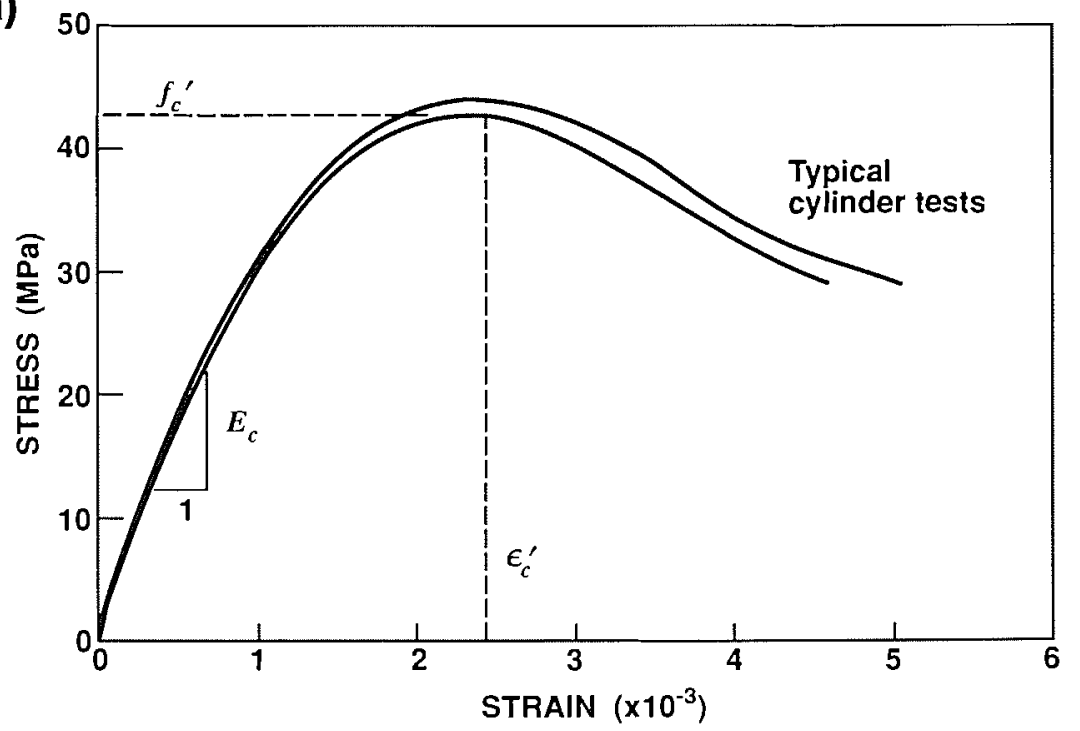

(b)

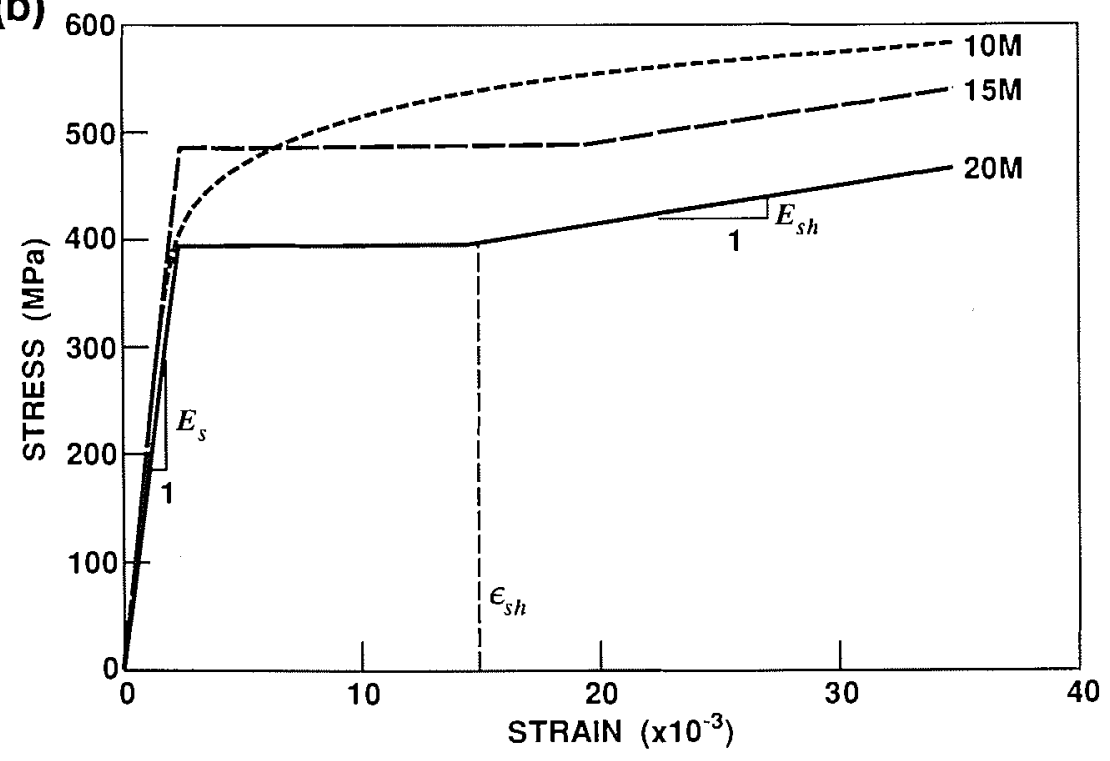

FIG. 2. Material stress-strain response curves: $(a)$ concrete; $(b)$ reinforcement. 


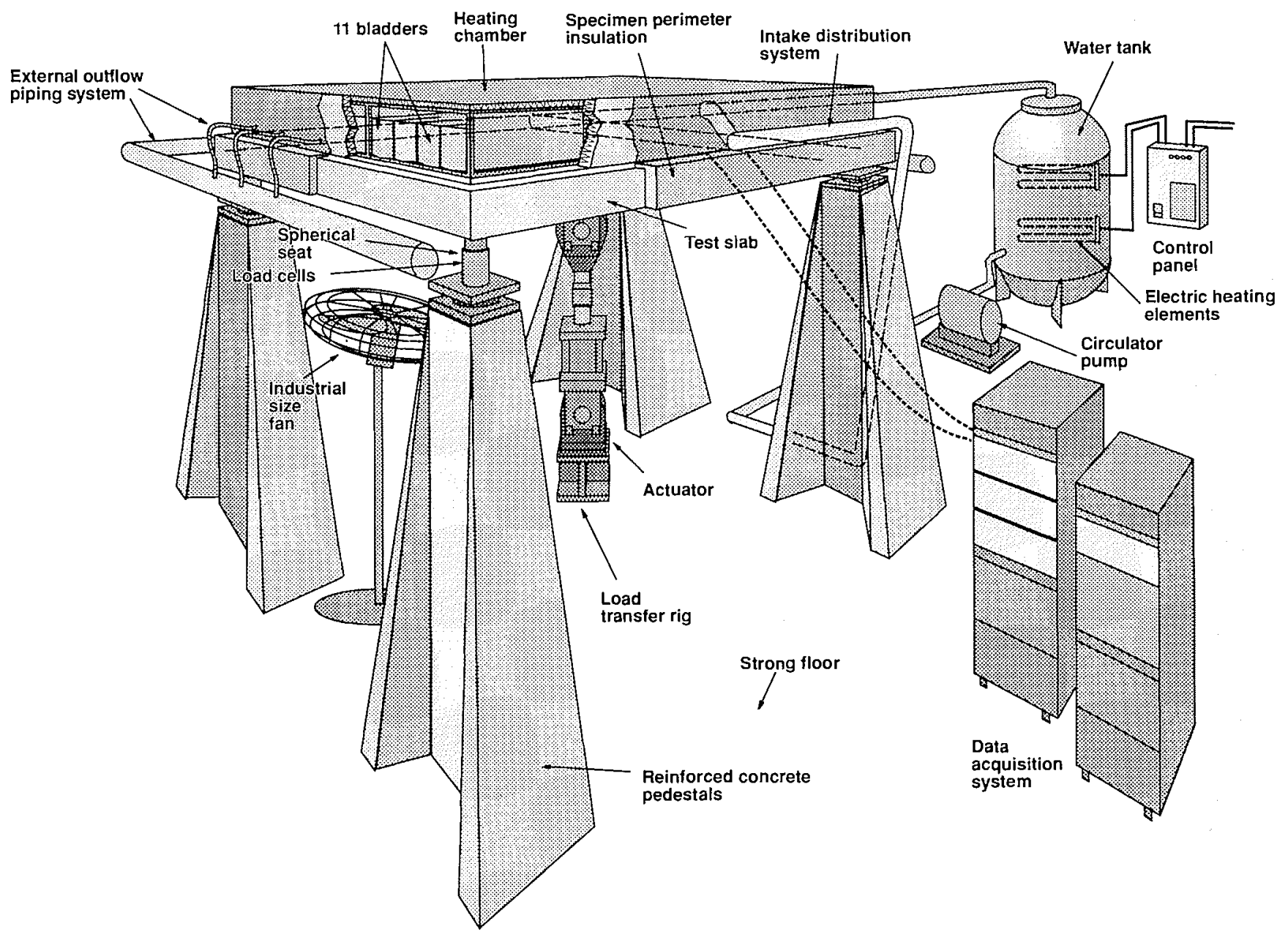

FIG. 3. Details of test setup.

that the test specimens would sustain little or no damage (i.e., cracking) as a result of this test.

The second phase of testing called for the thermal loads to be applied to the restrained specimens. The actuator was attached to the anchor plate at the slab centre, and operated in displacement control mode maintaining zero displacement at the centre. The thermal load applied was the same as that in phase I, and was maintained for 24 hours. The restrained thermal deformation of the slabs, resulting from the thermal gradients imposed, would give rise to the development of significant levels of internal force. These, in turn, would cause significant stressing of the concrete and reinforcement. The objective was to monitor the restraint forces developed, their dependence on reinforcement detailing, and their dissipation due to short-term thermal creep.

Under the third phase of loading, the actuator was used to apply an active mechanical load to the slabs at the same time as a steady state thermal gradient was acting. The mechanical load was monotonically increased until the ultimate capacity of the slab was achieved. The purpose was to obtain corroborative information for analyzing the restrained test results, to determine the influence of thermal gradients at high stress levels, and to obtain data for corroborating the finite element analysis program.

\section{Results of free thermal load tests}

The phase I testing was performed on only three of the test slabs: specimens TS4, TS5, and TS9. Theoretically, the
TABLE 3. Free thermal test results

\begin{tabular}{cccccc}
\hline \hline & \multicolumn{3}{c}{ Experiment } & & Theoretical \\
\cline { 2 - 3 } \cline { 6 - 6 } Specimen & $\begin{array}{c}\Delta \mathrm{T} \\
\left({ }^{\circ} \mathrm{C}\right)\end{array}$ & $\begin{array}{c}\text { Time } \\
(\mathrm{h})\end{array}$ & $\begin{array}{c}\Delta_{\mathrm{c}} \\
(\mathrm{mm})\end{array}$ & & $\begin{array}{c}\text { Deflection } \\
(\mathrm{mm})\end{array}$ \\
\hline TS4 & 30 & 5.6 & 1.79 & & 3.34 \\
TS5 & 30 & 5.9 & 1.86 & & 3.51 \\
TS9 & 30 & 6.0 & 2.02 & & 3.39 \\
\hline
\end{tabular}

slab deflections would be the same for all the test specimens, for a given thermal gradient, regardless of the reinforcement percentages or bar orientations.

Typical of the loading conditions and specimen response observed during the phase I testing are those associated with specimen TS5 (see Fig. 4). As the thermal load was applied, the top surface temperature of the slab increased by about $35^{\circ} \mathrm{C}$ while the bottom surface temperature increased by about $4^{\circ} \mathrm{C}$. The effective thermal gradient attained was $30^{\circ} \mathrm{C}$, with steady state conditions achieved about 6 hours after loading commenced. At steady state, the temperatures measured through the thickness of the slab showed the thermal gradient to be essentially linear.

The upward deflections measured at the centre of the slabs, for each of the three specimens tested, are given in Table 3. Note that the effective thermal gradients imposed, and the concrete's coefficient of thermal expansion, were essentially the same for all three specimens. The deflections 
(a)

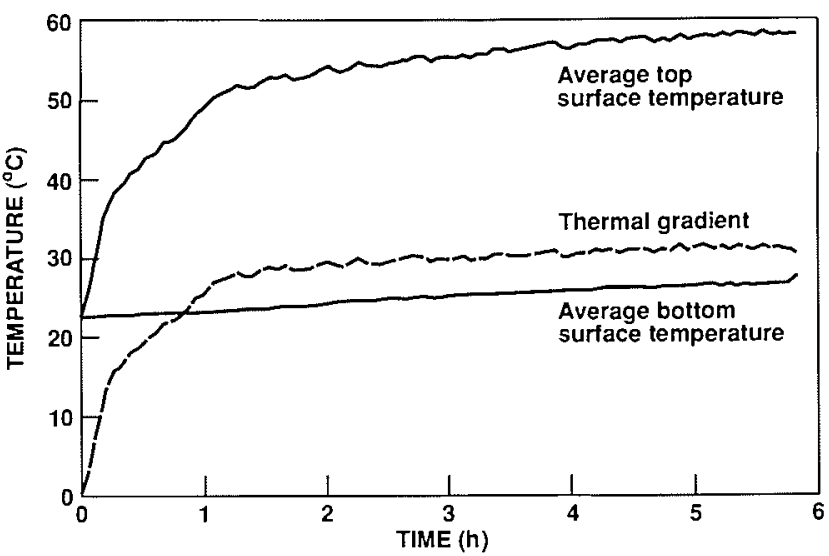

(b)

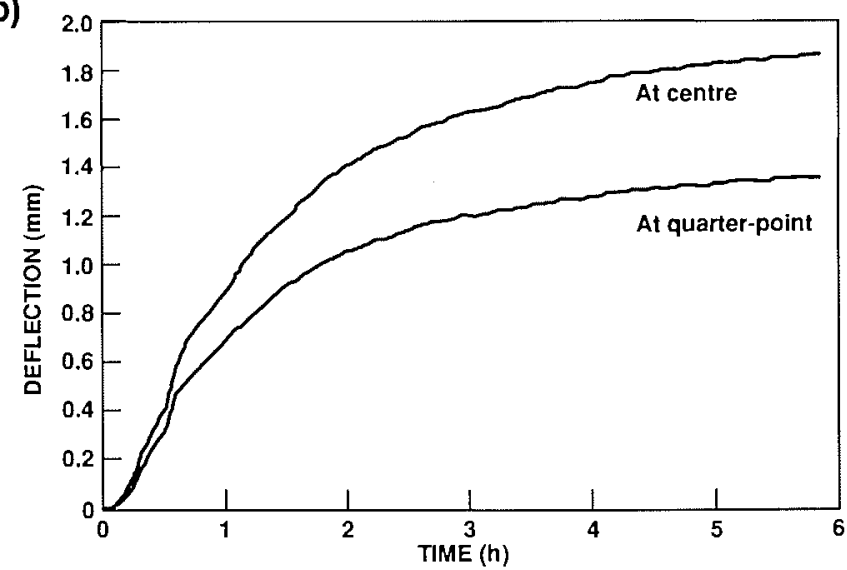

(c)

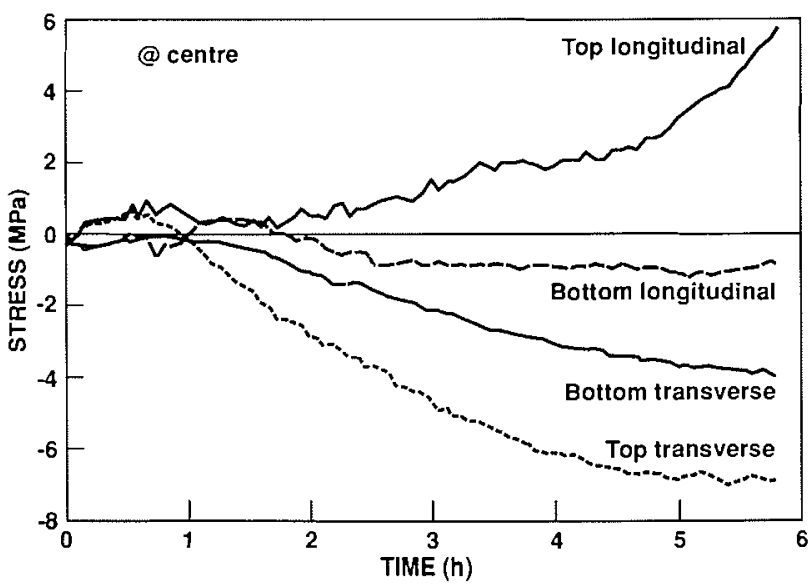

FIG. 4. Response of slab TS5 to phase I loading: (a) thermal load; (b) deflections; $(c)$ rebar stresses.

measured in the three specimens showed some variation $( \pm 10 \%)$, however. (The largest deflections occurred in specimen TS9, which was the most lightly reinforced.) The deflections increased rapidly shortly after the application of thermal load, and were at essentially stable values after 4 hours (e.g., see Fig. $4 b$ ).

The theoretical deflection of the slabs can be computed from the formula

[1] $\Delta_{\mathrm{c}}=\frac{\alpha_{\mathrm{c}} \Delta T l^{2}}{4 h}$

where $h$ is the slab thickness $(150 \mathrm{~mm}), l$ is the slab span (a)

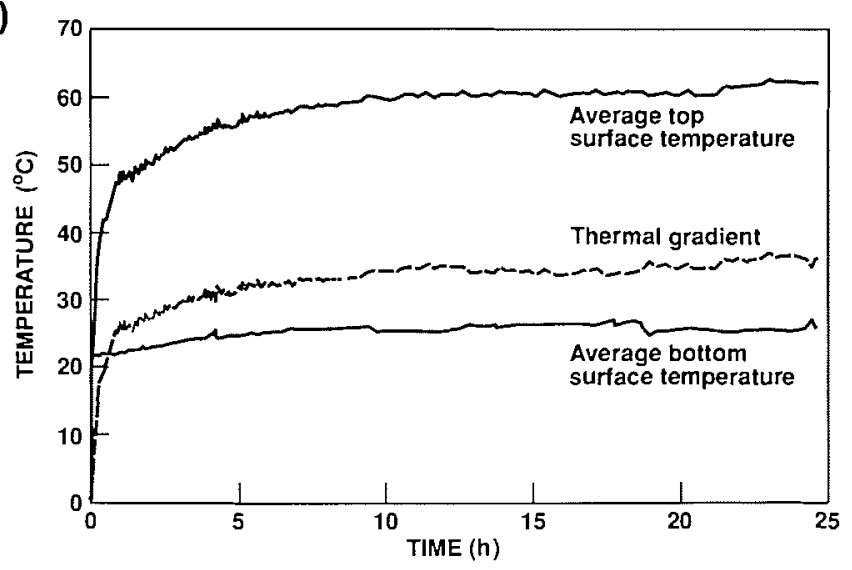

(b)

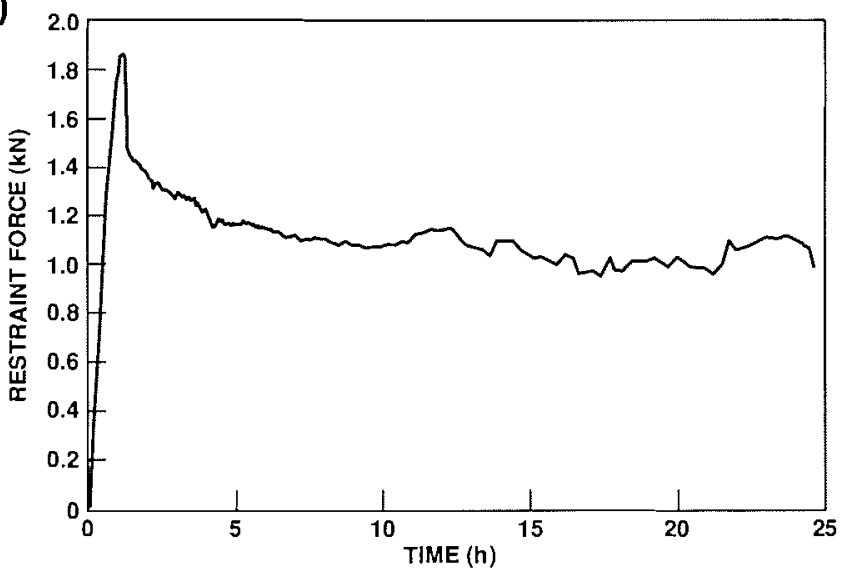

(c)

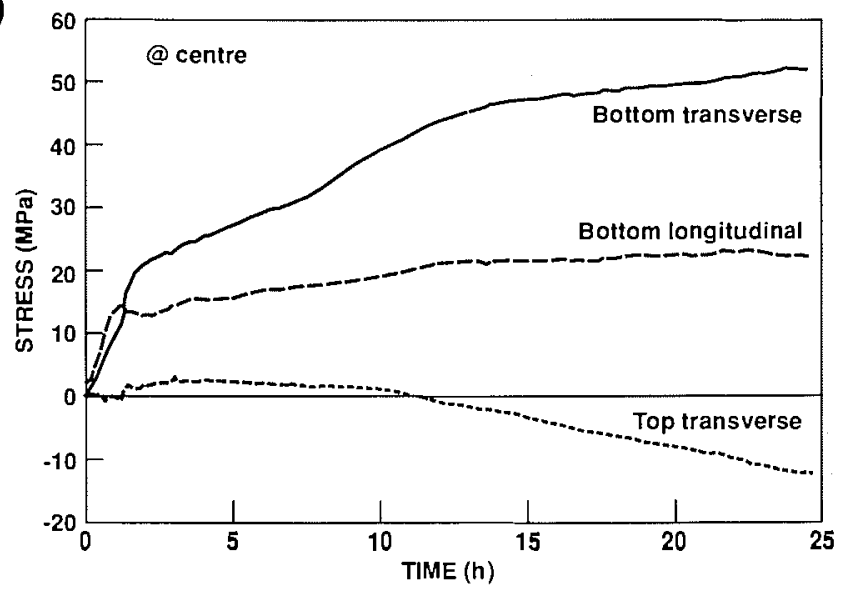

FIG. 5. Response of slab TS8 to phase II loading: (a) thermal load; $(b)$ restraint force; (c) rebar stresses.

(2500 mm), $\Delta T$ is the thermal gradient, and $\alpha_{\mathrm{c}}$ is the coefficient of expansion of the concrete. Use of this formula presumes that the entire top surfaces of the slabs are heated, and that the reinforcement has the same coefficient of thermal expansion as the concrete. As seen in Table 3, the measured deflections were significantly less than the corresponding theoretical values. The influence of the $150 \mathrm{~mm}$ wide unheated band around the perimeter of the specimens is thought to be in part responsible for the differences. As well, skin effects at the top and bottom surfaces are thought to partially negate the ef fective thermal load being applied.

The slabs were unrestrained and therefore not subjected to any external forces or reactions. Self-equilibrating inter- 
TABLE 4. Restrained thermal test results - restraint forces

\begin{tabular}{|c|c|c|c|c|c|c|c|c|c|c|c|}
\hline \multirow[b]{2}{*}{ Specimen } & \multicolumn{3}{|c|}{ At first cracking } & \multicolumn{3}{|c|}{ At peak load } & \multicolumn{2}{|c|}{ After 4 hours } & \multicolumn{3}{|c|}{ At test conclusion } \\
\hline & $\begin{array}{c}\text { Time } \\
(\mathrm{h})\end{array}$ & $\underset{\left({ }^{\circ} \mathrm{C}\right)}{\Delta \mathrm{T}}$ & $\begin{array}{c}P_{\mathrm{r}} \\
(\mathrm{kN})\end{array}$ & $\begin{array}{c}\text { Time } \\
\text { (h) }\end{array}$ & $\begin{array}{c}\Delta T \\
\left({ }^{\circ} \mathrm{C}\right)\end{array}$ & $\begin{array}{c}P_{\mathrm{r}} \\
(\mathrm{kN})\end{array}$ & $\begin{array}{c}\Delta T \\
\left({ }^{\circ} \mathrm{C}\right)\end{array}$ & $\begin{array}{c}P_{\mathrm{r}} \\
(\mathrm{kN})\end{array}$ & $\begin{array}{c}\text { Time } \\
\text { (h) }\end{array}$ & $\begin{array}{c}\Delta T \\
\left({ }^{\circ} \mathrm{C}\right)\end{array}$ & $\begin{array}{c}P_{\mathrm{r}} \\
(\mathrm{kN})\end{array}$ \\
\hline TS2 & 1.8 & 25 & 27.9 & 1.8 & 25 & 27.9 & 24 & 19.1 & 25.7 & 35 & 8.1 \\
\hline TS3 & 0.8 & 22 & 14.2 & 1.3 & 28 & 15.4 & 30 & 11.0 & 24.8 & 35 & 0.0 \\
\hline TS4 & 1.2 & 27 & 13.8 & 1.2 & 27 & 13.8 & 31 & 9.1 & 24.5 & 37 & 7.6 \\
\hline TS5 & 2.0 & 24 & 25.0 & 2.7 & 27 & 25.3 & 29 & 22.4 & 25.0 & 35 & 16.8 \\
\hline TS6 & 1.6 & 27 & 16.8 & 1.5 & 28 & 17.1 & 32 & 14.3 & 24.3 & 34 & 7.9 \\
\hline TS7 & 0.5 & 20 & 9.5 & 1.3 & 28 & 12.7 & 33 & 7.4 & 24.6 & 38 & 6.0 \\
\hline TS8 & 1.2 & 26 & 23.2 & 1.2 & 26 & 23.2 & 31 & 20.2 & 24.5 & 37 & 12.8 \\
\hline TS9 & 1.0 & 25 & 24.3 & 1.6 & 26 & 24.7 & 32 & 22.2 & 24.8 & 34 & 12.6 \\
\hline
\end{tabular}

nal stresses would have developed, however, due to nonlinear thermal gradients and due to differences in coefficients of thermal expansion between the concrete and the reinforcement. Shown in Fig. $4 c$ are the stresses developed in the reinforcement in slab TS5. Here, and with the other specimens, the stresses were relatively small and insignificant. Given the low values, the measured stresses were susceptible to errors due to inaccurate temperature correction and due to drift. In no specimen were cracks seen to develop as a result of the phase I loading.

\section{Results of restrained thermal load tests}

In the phase II tests, the slabs were subjected to thermal loads while restrained from upwards deflections at the centre. The restraint was provided by a servo-controlled actuator, acting in displacement control mode, set to maintain zero displacement. This resulted in the development of significant levels of restraint force and, consequently, stressing and cracking of the slabs.

In general, the restraint forces were observed to develop rapidly with the application of thermal load. The restraint forces typically peaked at about 1.2-1.6 hours after the onset of loading, with the effective thermal gradient at the time being around $26-28^{\circ} \mathrm{C}$. At about this point in time, the slabs typically began to experience cracking on the underside towards the centre. With the emergence of cracks, the restraint forces showed a tendency to drop abruptly or to level off and then begin to diminish. Thereafter, although the effective thermal gradient continued to increase gradually and ultimately achieved a level of about $35^{\circ} \mathrm{C}$, the restraint forces were unable to re-attain the peak values. The response of slab TS8, shown in Fig. 5, is representative of the behaviour observed; the results for all specimens are listed in Table 4. Thus, the initial cracking caused a loss in slab stiffness which, under the deformation-controlled loading condition imposed, resulted in an immediate and substantial relaxation in the restraint forces. At the relatively low levels of thermal load imposed, the peak forces attained appeared dictated primarily by the concrete tensile strength and not by the reinforcement. There was no discernable relation between the peak restraint forces and the pattern or orientation of the reinforcement.

The thermal loads were maintained for periods of 24 hours, with the effective thermal gradients essentially stable and constant from about 6 hours after application onward. However, the restraint forces tended to diminish with time. The majority of the relaxation occurred within the first 3 hours of testing. After 24 hours, the total losses ranged from $34 \%$ to $100 \%$ (see Table 4 ). The degree of force relaxation observed among the specimens did not appear to be strongly influenced by the amount or orientation of the reinforcement present.

Although the restraint forces tended to show considerable relaxation, this was not the case with the reinforcement stresses measured. Typically, the rebar stresses rose more gradually than did the restraint forces, and reached maximum values after 12-24 hours. The longitudinal and transverse reinforcement on the bottom face developed tensile stresses up to $60 \mathrm{MPa}$. Stresses in the top face reinforcement varied between compressive and tensile, in some cases reversing sign midway through the test, but typically low in magnitude. The rebar stresses measured in specimen TS 8 are shown in Fig. $5 c$.

First cracking of the specimens was noted typically about 1.0 hour after load application, at a thermal gradient of about $20-26^{\circ} \mathrm{C}$. The first cracks tended to develop parallel to the strong reinforcement direction, on the underside near the centre of the slab. In those specimens more lightly reinforced in one direction, the cracks perpendicular to the weak reinforcement direction were typically slightly more prominent. As the tests progressed, existing cracks propagated and new cracks formed, even though the restraint forces had diminish and were continuing to diminish. The crack patterns and crack widths tended to stabilize after about 12 hours. The final crack widths varied between 0.05 and $0.20 \mathrm{~mm}$, with the majority being about $0.05-0.10 \mathrm{~mm}$ in width.

\section{Results of pull-down tests}

In phase III testing, a uniform thermal load was maintained on the test slabs while a downward mechanical load was applied at the centre of the specimen by use of the actuator. An effective thermal gradient of about $36^{\circ} \mathrm{C}$ was present throughout the test. The mechanical load was monotonically increased until the ultimate load capacity of the slab was reached.

The load-deformation response of the slabs typically showed a gradually-softening nonlinear behaviour. Because the specimens had sustained cracking during phase II testing, there was no sharp transition between pre-cracking and postcracking stiffness. As load increased, however, the propagating cracks resulted in progressively lower stiffness. The 
(a)

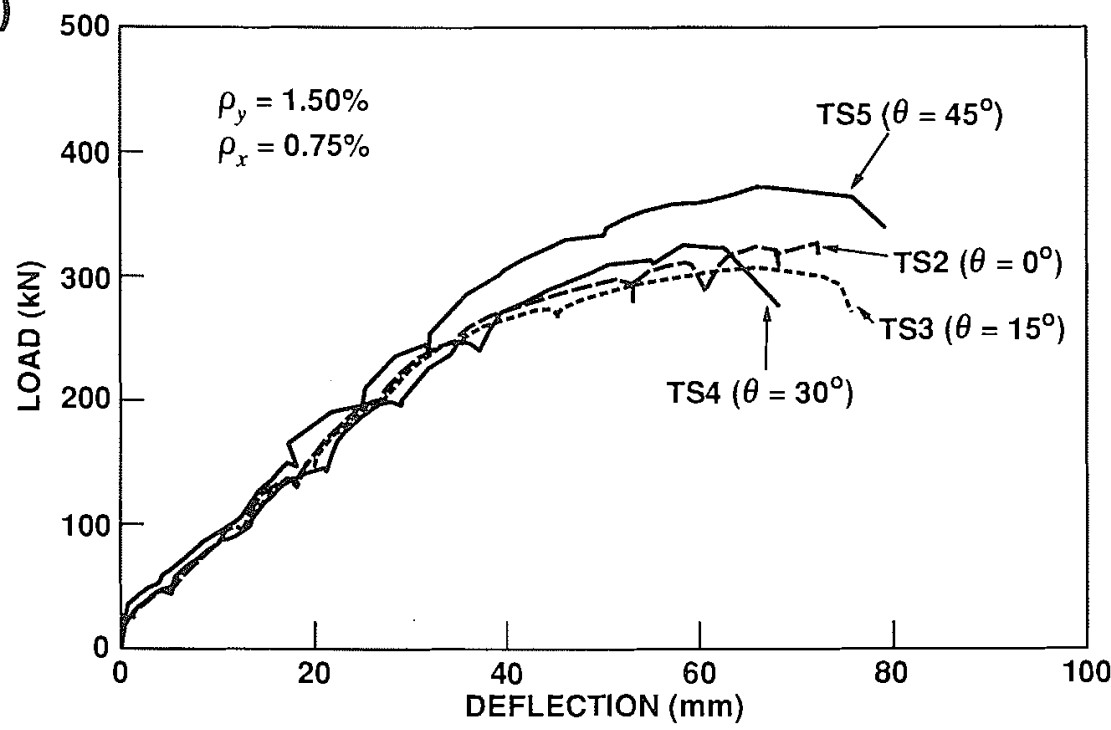

(b)

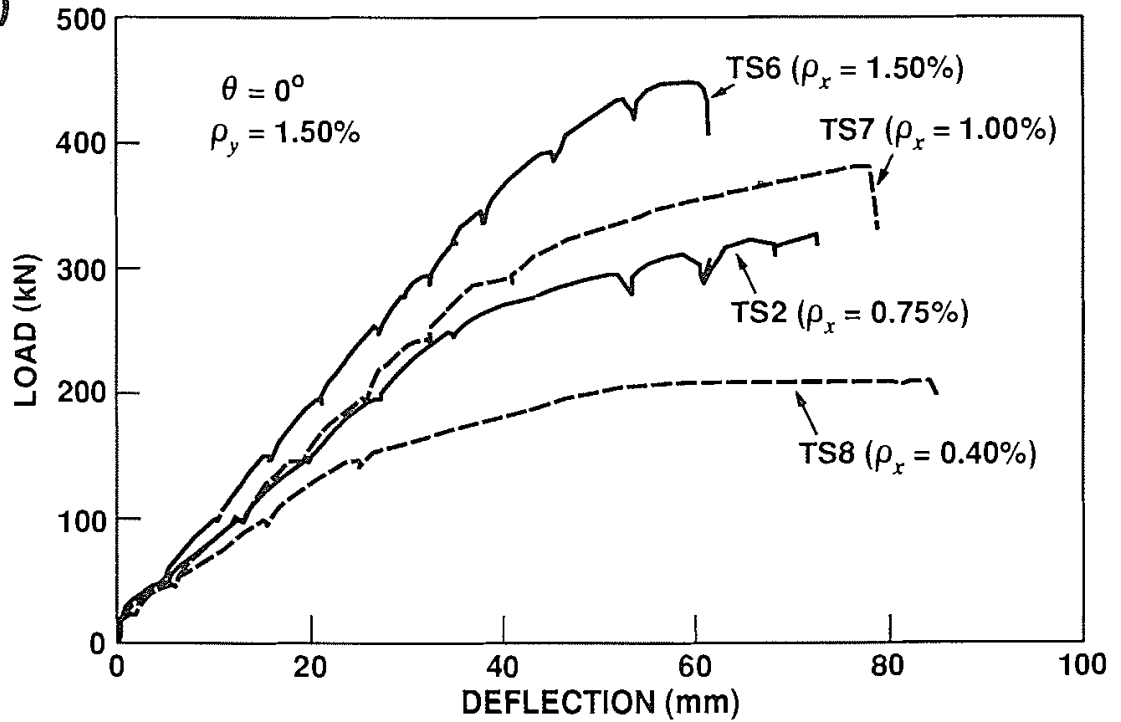

FIG. 6. Response of slabs to phase III loading: $(a)$ slabs varying in reinforcement orientation; $(b)$ slabs varying in reinforcement ratio.

slabs' ultimate capacity was typically achieved at deflections of about $h / 2(75 \mathrm{~mm})$. The response of slabs is summarized in Fig. 6 and Table 5.

The ultimate load capacities of the slabs showed considerable variation, and were obviously dictated by the percentage of reinforcement provided. In all cases except TS2, yielding of the bottom reinforcement was prevalent at ultimate load. In the slabs more lightly reinforced in one direction (e.g., TS8 and TS9), yielding was limited to the bottom transverse reinforcement only. In the more uniformly reinforced slabs (e.g., TS6 and TS7), yielding was also experienced in the bottom longitudinal reinforcement. With slab TS2, the ultimate condition was imminent but the test was terminated prematurely due to stability problems at the supports. Interestingly, with specimens TS2 to TS5, where the amounts of reinforcement were similar but the orientations differed, significant differences in ultimate capacity were observed. The highest capacities were achieved when the reinforcement was placed at either $0^{\circ}$ or $45^{\circ}$ to the slab sides (see Fig. $6 a$ ).

The failure modes at ultimate ranged from sheardominant to flexure-dominant mechanisms. In all but the most lightly reinforced slabs (i.e., TS8 and TS9), failure was accompanied by crushing of the concrete on the top surface. In slabs TS4 and TS5, both with skew direction reinforcement, a shear failure occurred near one of the supports. Slab TS3, having slightly skewed reinforcement, experienced flexural-shear failure midway along one of the sides. The others experienced predominantly flexural type failures.

In all slabs, the crack patterns in the centre regions tended to follow the reinforcement in terms of crack orientation and crack spacing. In the corner regions, some radial cracking was observed, beginning at load levels of about $150-200 \mathrm{kN}$. Near ultimate load, regardless of the reinforcement orientation, cracks propagated out from the centre plate towards the four corner supports. At ultimate load, crack widths were as much as $10.0 \mathrm{~mm}$.

Apart from causing a degradation in stiffness due to the previous development of internal and external cracks, the thermal load was perceived to have little influence on the slab's behaviour during this phase of testing. There was no evidence to indicate that the ultimate capacities or failure modes were influenced in any way. 
TABLE 5. Pull-down test results

\begin{tabular}{|c|c|c|c|c|c|c|c|c|}
\hline Specimen & $\begin{array}{l}\Delta T_{\text {avg }} \\
\left({ }^{\circ} \mathrm{C}\right)\end{array}$ & $\begin{array}{c}P_{\mathrm{ul}} \\
(\mathrm{kN})\end{array}$ & $\begin{array}{l}\Delta_{\mathrm{c}} \text { at } P_{\mathrm{ult}} \\
(\mathrm{mm})\end{array}$ & $\begin{array}{l}\Delta_{c_{\operatorname{mix}}} \\
(\mathrm{mm})\end{array}$ & $\begin{array}{l}\text { Failure } \\
\text { mode }\end{array}$ & $\begin{array}{l}\text { Failure } \\
\text { location }\end{array}$ & $\begin{array}{c}\text { Rebar } \\
\text { yielded* }\end{array}$ & $\begin{array}{l}\text { Top concrete } \\
\text { crushing }\end{array}$ \\
\hline TS2 & 36 & $328^{\dagger}$ & 72.5 & 72.6 & na & na & None & Near centre plate \\
\hline TS3 & 35 & 306 & 64.3 & 75.8 & $\begin{array}{l}\text { Flexure } \\
\text {-shear }\end{array}$ & $\begin{array}{l}\text { Centre of } \\
\text { north side }\end{array}$ & $\begin{array}{l}\text { TT (centre) } \\
\text { BL (centre) }\end{array}$ & $\begin{array}{l}\text { Near centre plate } \\
\text { in north-south } \\
\text { direction }\end{array}$ \\
\hline TS4 & 37 & 325 & 68.4 & 72.5 & Shear & $\begin{array}{l}\text { Near } \\
\text { southeast } \\
\text { support }\end{array}$ & $\begin{array}{l}\text { BT (centre) } \\
\text { BL (centre) } \\
\text { BT (northeast) } \\
\text { BL (southeast) }\end{array}$ & $\begin{array}{l}\text { At shear failure } \\
\text { location }\end{array}$ \\
\hline TS5 & 35 & 371 & 66.0 & 79.5 & Shear & $\begin{array}{l}\text { Near } \\
\text { northwest } \\
\text { support }\end{array}$ & $\begin{array}{l}\text { TT (centre) } \\
\text { BT (centre) }{ }^{\ddagger} \\
\text { BL (centre) } \\
\text { BL (northwest) }\end{array}$ & $\begin{array}{l}\text { At shear failure } \\
\text { location }\end{array}$ \\
\hline TS6 & 35 & 440 & 52.9 & 61.6 & Flexure & $\begin{array}{l}\text { Near centre } \\
\text { plate on } \\
\text { underside }\end{array}$ & $\begin{array}{l}\text { BT (centre) } \\
\text { BL (centre) }\end{array}$ & $\begin{array}{l}\text { North-south } \\
\text { direction from } \\
\text { centre plate }\end{array}$ \\
\hline TS7 & 37 & 385 & 78.0 & 78.9 & Flexure & $\begin{array}{l}\text { Near centre } \\
\text { plate on } \\
\text { underside }\end{array}$ & $\begin{array}{l}\text { TT (centre) } \\
\text { BT (centre) } \\
\text { BL (southwest) } \\
\text { BT (south) }\end{array}$ & $\begin{array}{l}\text { North-south } \\
\text { direction from } \\
\text { centre plate }\end{array}$ \\
\hline TS8 & 36 & 210 & 80.0 & 84.9 & Flexure & $\begin{array}{c}\text { Near centre } \\
\text { plate on } \\
\text { underside }\end{array}$ & $\begin{array}{l}\text { TT (centre) })^{\ddagger} \\
\text { BT (centre) }\end{array}$ & No \\
\hline TS 9 & 35 & 207 & 81.7 & 86.7 & Flexure & $\begin{array}{l}\text { Near centre } \\
\text { plate on } \\
\text { underside }\end{array}$ & $\begin{array}{l}\text { TT (centre) }{ }^{\ddagger} \\
\text { BT }{\text { (centre })^{\ddagger}}^{\text {(c) }}\end{array}$ & No \\
\hline
\end{tabular}

${ }^{*} \mathrm{TL}=$ top longitudinal; $\mathrm{TT}=$ top transverse; $\mathrm{BL}=$ bottom longitudinal; $\mathrm{BT}=$ bottom transverse.

${ }^{\dagger}$ Did not reach ultimate conditions.

†Strain hardened.

(a)

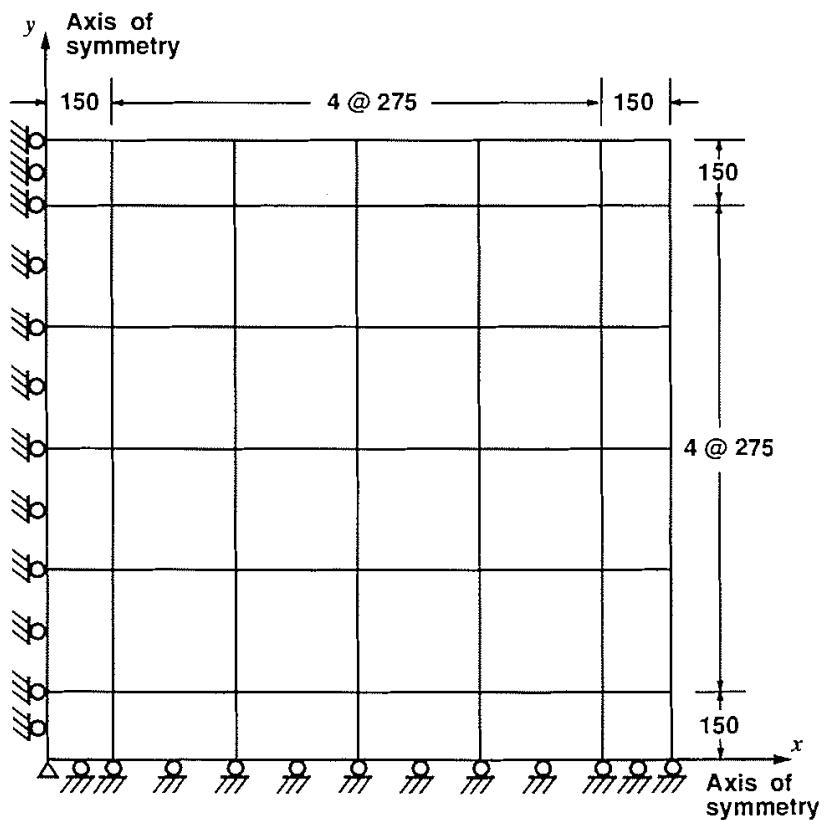

(b)

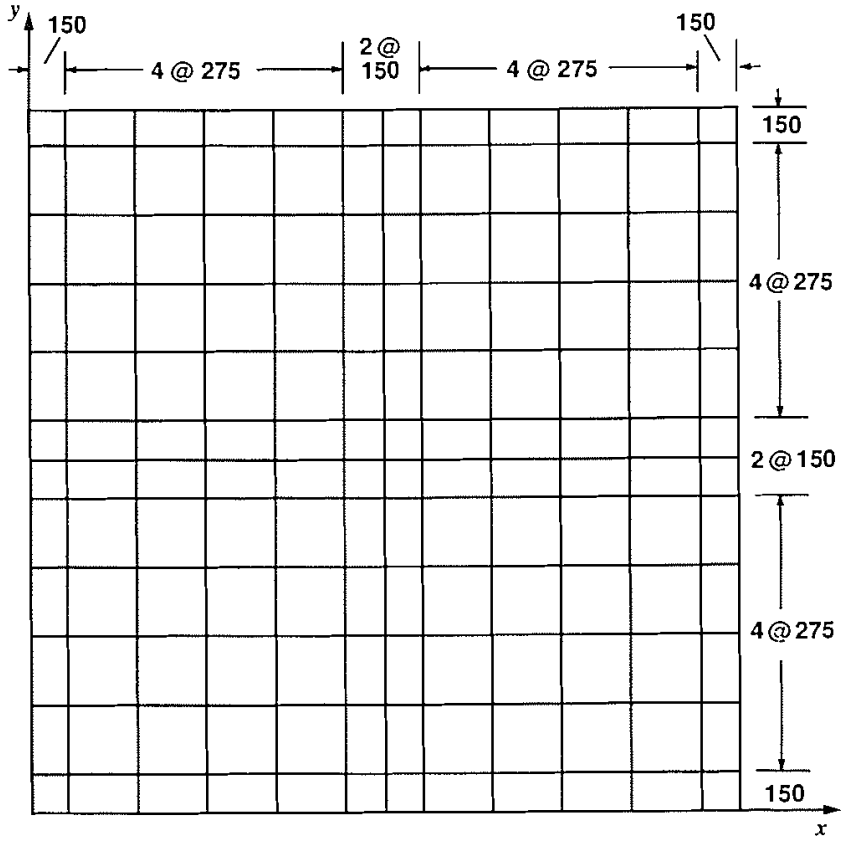

FIG. 7. Finite element modelling of test slabs: (a) TS2, TS6-TS9; (b) TS3-TS5. (All dimensions are in millimetres.)

Finite element analysis

The test slabs were modelled using the nonlinear finite element program APECS (Polak and Vecchio 1993). The program was specially developed for the analysis of reinforced concrete shells subjected to thermal and mechanical loads. A three-dimensional degenerate isoparametric quad- 
TABLE 6. Finite element analysis results

\begin{tabular}{|c|c|c|c|c|c|c|}
\hline \multirow[b]{2}{*}{ Specimen } & \multicolumn{3}{|c|}{$\begin{array}{l}\text { Peak restraint forces } \\
\text { (Phase II tests) }\end{array}$} & \multicolumn{3}{|c|}{$\begin{array}{l}\text { Ultimate load capacity } \\
\text { (Phase III tests) }\end{array}$} \\
\hline & $\begin{array}{l}P_{\mathrm{r}(\exp )} \\
(\mathrm{kN})\end{array}$ & $\begin{array}{l}P_{\mathrm{r}(\mathrm{theer})} \\
(\mathrm{kN})\end{array}$ & $\frac{\text { Experimental }}{\text { Theoretical }}$ & $\begin{array}{l}P_{\mathrm{u}(\mathrm{exp})} \\
(\mathrm{kN})\end{array}$ & $\begin{array}{l}P_{\text {u(theor })} \\
(\mathrm{kN})\end{array}$ & $\frac{\text { Experimental }}{\text { Theoretical }}$ \\
\hline TS2 & 27.9 & 74.5 & 0.374 & 328 & 270 & $1.213^{*}$ \\
\hline TS3 & 15.4 & 68.3 & 0.225 & 306 & 310 & 0.987 \\
\hline TS4 & 13.8 & 57.4 & 0.240 & 325 & 330 & 0.985 \\
\hline TS5 & 25.3 & 70.6 & 0.358 & 371 & 375 & 0.989 \\
\hline TS6 & 17.1 & 74.0 & 0.231 & 440 & 470 & 0.936 \\
\hline TS7 & 12.7 & 71.9 & 0.177 & 385 & 390 & 0.987 \\
\hline TS8 & 23.2 & 63.9 & 0.363 & 210 & 210 & 1.000 \\
\hline TS9 & 24.7 & 67.1 & 0.368 & 207 & 210 & 0.986 \\
\hline Mean & & & 0.292 & & & 0.981 \\
\hline $\operatorname{COV}(\%)$ & & & 27.8 & & & 2.1 \\
\hline
\end{tabular}

*Excluded from statistical averages due to premature failure.
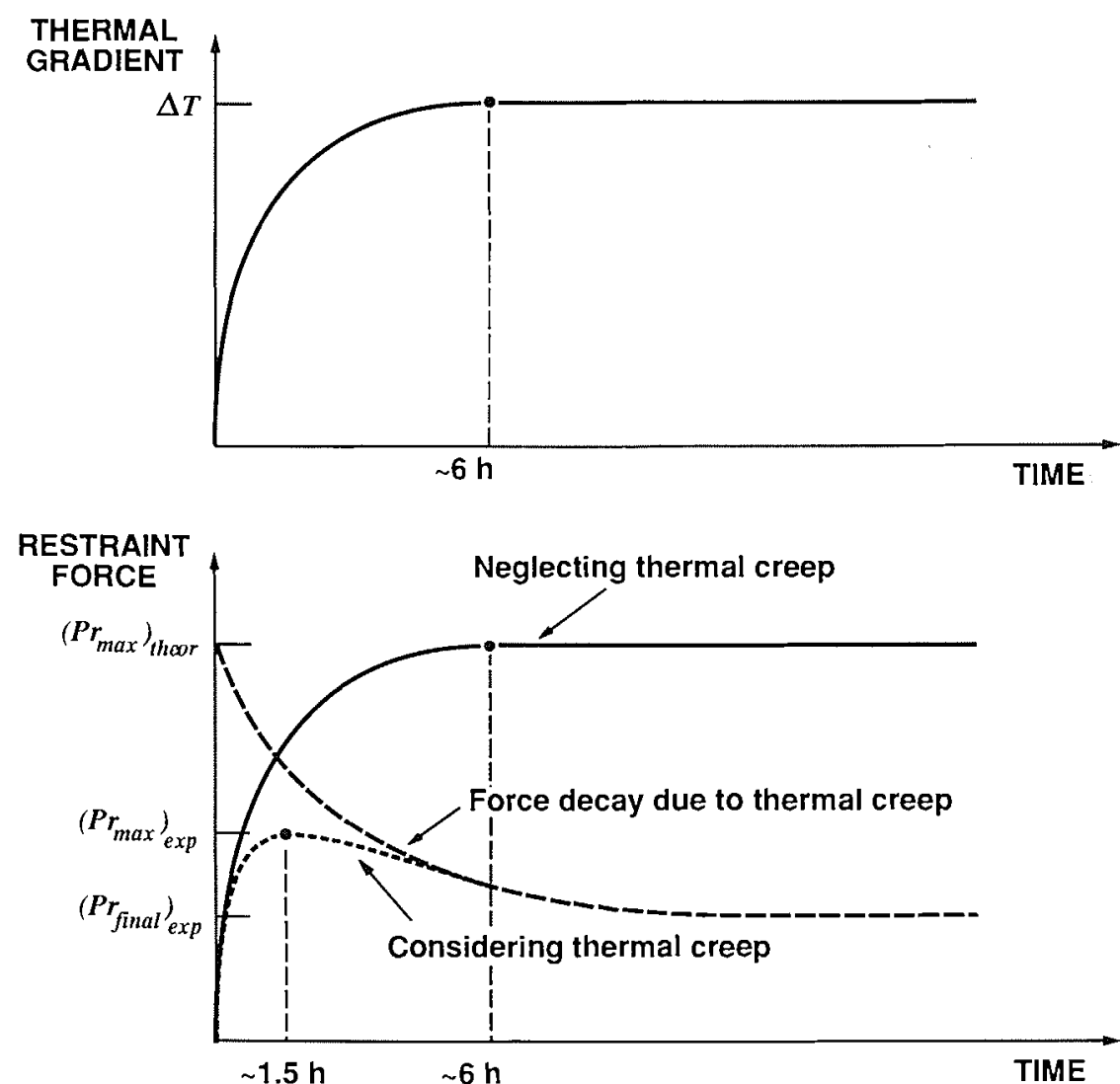

FiG. 8. Influence of thermal creep on peak restraint force.

rilateral element was developed and implemented in a secant stiffness analysis algorithm. The formulation is based on a smeared, rotating crack model for reinforced concrete, treating the concrete as an orthotropic nonlinear elastic material. The material models incorporated were those presented in the modified compression field theory (Vecchio and Collins 1986). Included were constitutive models for cracked concrete in compression, reflecting compression softening effects, and for cracked concrete in tension, representing tension stiffening effects.

The element meshes used to model the test slabs are shown in Fig. 7. A quarter-model, using 36 elements, was used to represent the specimens in which the in-plane reinforcement was oriented parallel to the slab side (Fig. 7a). The slabs containing skew-direction reinforcement was modelled in their entirety using 144 elements (Fig. $7 \mathrm{~b}$ ). The large number of elements used was required to properly capture the stress variations at the supports and load-application point. Longitudinal and transverse reinforcement were modelled as smeared, consistent with the reinforcement locations and amounts present in the test slabs. Out-of-plane reinforcement was also included in the modelling; appropriate percentages of shear reinforcement were specified for the slabs' corner and centre region elements, again consistent with that 

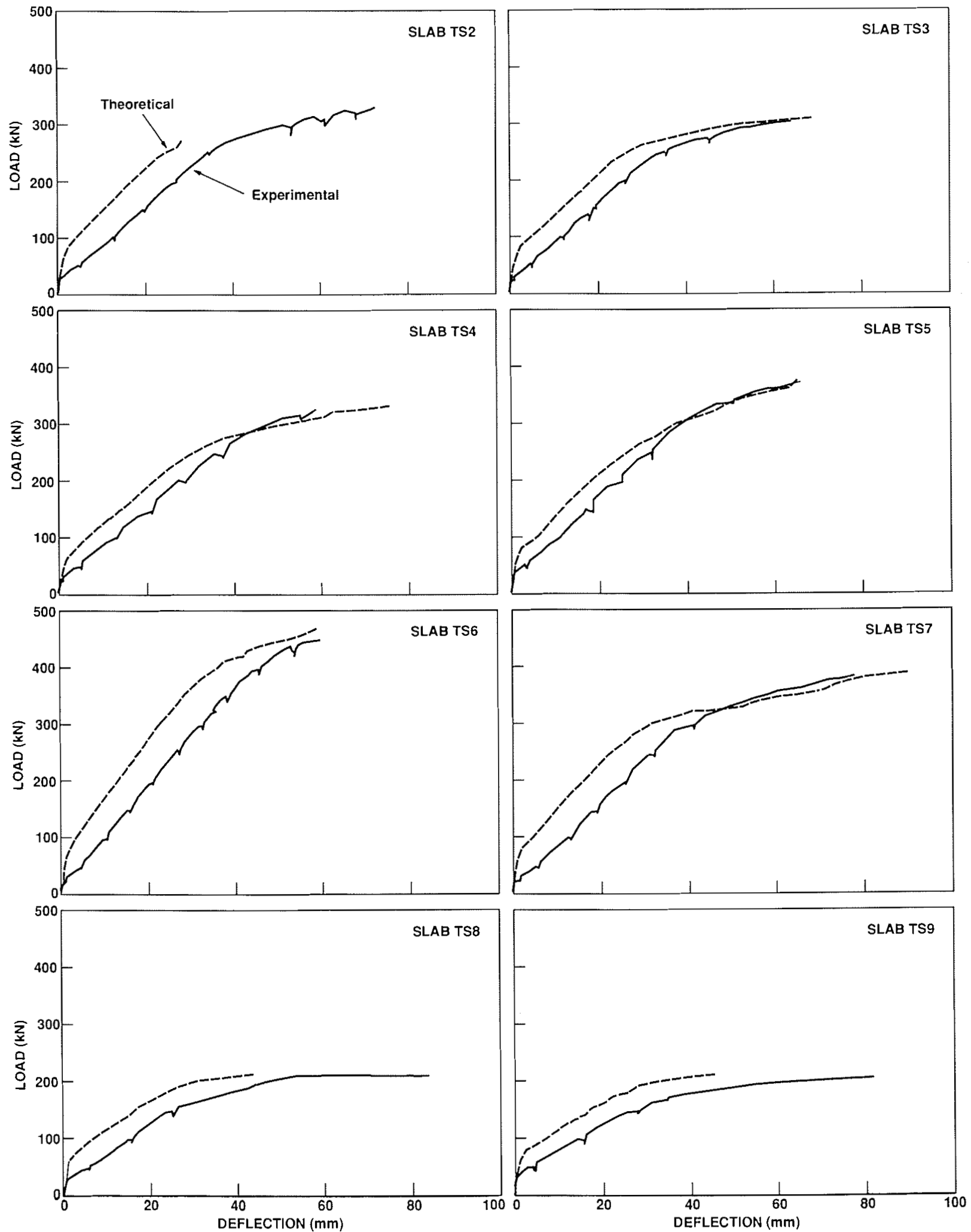

FiG. 9. Comparison of theoretical and experimental load-deformation responses of slabs.

provided in the test slabs. The material properties used for the concrete and reinforcement were those determined from the test cylinders and coupons, as reported earlier. (Note that the full stress-strain response curve for concrete was modelled; hence, effective moduli of elasticity varied from load stage to load stage, and from element to element.)
In analyzing the phase II tests, loads were imposed on the slabs producing centre deflections equal in magnitude to those observed during the phase I tests (i.e., $\sim 1.90 \mathrm{~mm}$ ). No attempt was made to model the nonuniform, transient nature of the thermal loading. Also, the program did not have facilities that allowed for the consideration of force 
(a)

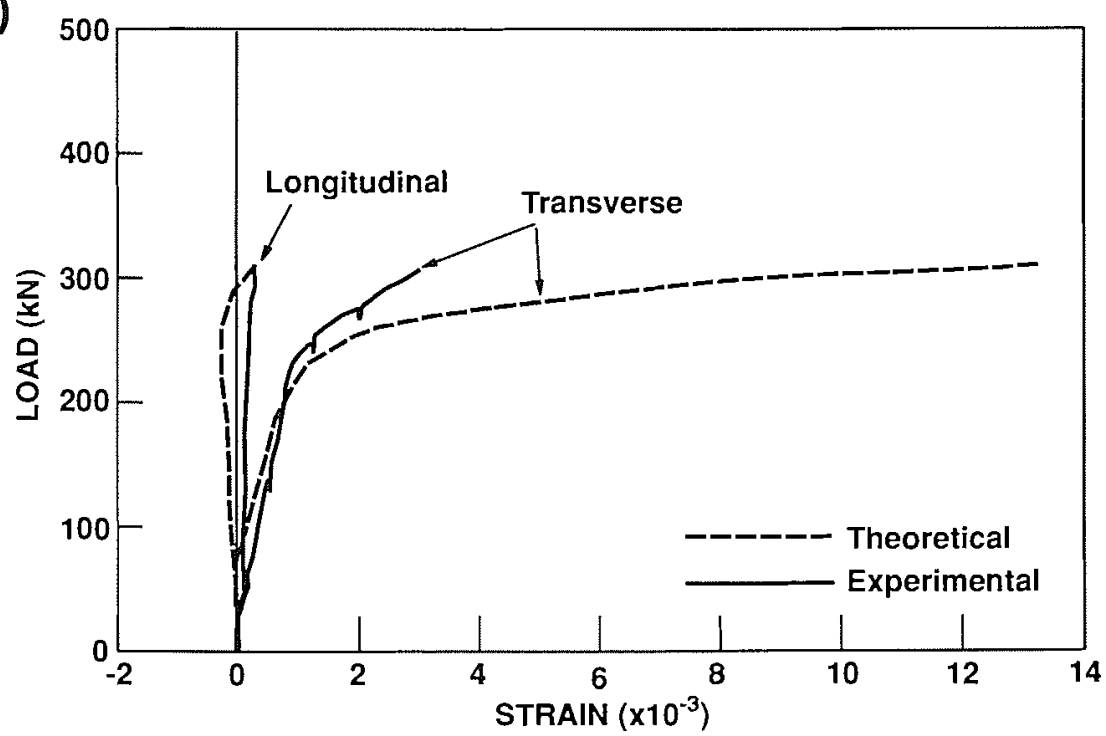

(b)

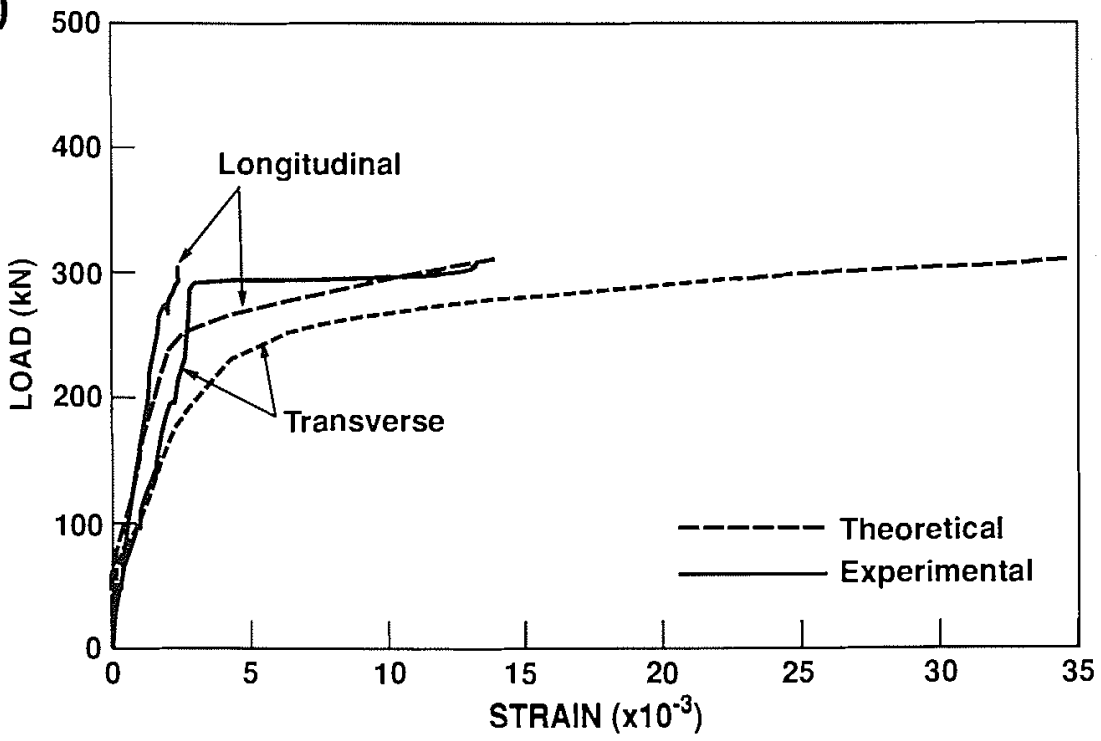

FIG. 10. Comparison of theoretical and experimental rebar stresses for slab TS3: $(a)$ top reinforcement; $(b)$ bottom reinforcement.

relaxation due to thermal creep effects. Compared in Table 6 are the predicted and observed restraint forces corresponding to the phase II thermal loads. The predicted forces are seen to be significantly greater than those measured. The influence of short-term thermal creep, which was considerable as evidenced by the large relaxations observed during the tests, is thought to be the primary reason for the disparity. The nature of the influence is illustrated in Fig. 8; $\left(\operatorname{Pr}_{\max }\right)_{t h e o r}$ would be the restraint force obtained from the finite element analysis, and $\left(\operatorname{Pr}_{\max }\right)_{\exp }$ would be the corresponding experimental value. As well, existing shrinkage cracks in some specimens, and possible internal cracking due to the phase I testing, may have contributed to the lower experimental stiffnesses.

The phase III tests were simulated by applying a load at the centre of the slabs and increasing the load until ultimate load capacity was reached. The program did not have capabilities for determining post-ultimate behaviour. Compared in Fig. 9 are the predicted load-deformation responses against the observed behaviours, for each of the test specimens. The predicted responses are seen to have initially higher stiffnesses than observed in the test specimens. This is largely due to the fact that the slabs were extensively pre-cracked as a result of the restrained (phase II) tests conducted beforehand. This initial cracked state was not taken into account in the phase III test modelling. However, it can be seen that the post-cracking stiffness and ductility near ultimate load show good agreement.

The ultimate load capacities predicted by the analyses correlated reasonably well with the test results (see Table 6). For the 8 specimens, the ratio of the experimental to predicted load capacity had a mean of 0.98 and a coefficient of variation of $2.1 \%$.

The finite element analyses predicted failure modes involving yielding of the longitudinal and transverse reinforcement in slabs TS4 to TS9, yielding of the transverse reinforcement only in slabs TS9, and shear failure in slabs TS3 to TS5. Concrete crushing on the top surface near the midspan, and along the shear failure planes, accompanied the yielding. In most cases, the predicted failure modes corresponded well with those observed.

Shown in Fig. 10 is a comparison of the computed and 
measured rebar stresses for slab TS3. The good correlations indicated are representative of those obtained for all specimens.

\section{Conclusions}

An experimental program was undertaken to study thermal loading effects in reinforced concrete shell structures. Eight large-scale reinforced concrete slabs were constructed and tested. The specimens differed in the amount and orientation of reinforcement provided. The three-phase loading regime used involved combinations of thermal and mechanical loads. The thermal load conditions considered were low level $\left(\sim \Delta T=40^{\circ} \mathrm{C}\right)$, typical of the magnitude encountered by some structures under service conditions.

It was observed that the specimens, when restrained against free thermal deformation, developed significant levels of internal force. As a result, the structures sustained extensive stressing and cracking. The restraint forces were seen to develop quickly, reaching peak values well before the acting thermal gradient attained maximum or steady state conditions. After first cracking occurred, however, the resulting losses in stiffness caused immediate relaxations in force. Thermal creep effects also resulted in substantial losses in thermal-induced force, with decays in force of about $40 \%$ in as little time as 24 hours. At ultimate conditions, the thermal loads were seen to have little influence on the capacity or failure mode of the structure.

Nonlinear finite element analyses were shown to provide fairly accurate modelling of the load-deformation responses, stresses, and failure modes of the specimens. However, critical to the analyses was the inclusion of a constitutive model for concrete post-cracking tensile stresses (i.e., tension stiffening effects). Without the use of such a model the postcracking restraint forces were found to be significantly underestimated. Also important in modelling the specimen's behaviour was the consideration of out-of-plane shear behaviour. The analyses for thermal load would likely be much improved, however, if provisions could be made for considering short-term thermal creep.

\section{Acknowledgements}

The work summarized in this paper was funded by a grant from the Natural Sciences and Engineering Research Council of Canada, as part of their university-industry cooperative research program. The authors are much appreciative of the support received. The substantial contributions from Ontario Hydro are also gratefully acknowledged.
ACI Committee 349. 1980. Reinforced concrete design for thermal effects on nuclear power plant structures. ACI 349.1 R-80, American Concrete Institute, Detroit, Mich.

ACI Committee 435. 1985. State-of-the-art report on temperatureinduced deflections of reinforced concrete members. $\mathrm{ACl}$ 435.7R-85, American Concrete Institute, Detroit, Mich.

Polak, M.A., and Vecchio, F.J. 1993. Nonlinear analysis of reinforced concrete shells. ASCE Journal of the Structural Division. In press.

Priestley, M.J.N. 1981. Thermal stresses in concrete structures. Proceedings, Structural Concrete Conference, Toronto, Ont., pp. 255-283.

Thurston, S.J., Priestley, M.J.N., and Cooke, N. 1980. Thermal analysis of thick concrete sections. American Concrete Institute Journal 77(5): 347-357.

Vecchio, F.J. 1987. Nonlinear analysis of reinforced concrete frames subjected to thermal and mechanical loads. American Concrete Institute Journal, 84(6): 492-501.

Vecchio, F.J., and Collins, M.P. 1986. The modified compression field theory for reinforced concrete elements subject to shear. American Concrete Institute Journal, 83(2): 219-231.

Vecchio, F.J., and Sato, J.A. 1990. Thermal gradient effects in reinforced concrete frame structures. American Concrete Institute Journal, 87(3): 262-275.

\section{List of symbols}

$A_{\mathrm{s}}$ cross-sectional area of reinforcing bar

$E_{\mathrm{c}}$ initial tangent modulus of elasticity of concrete

$E_{\mathrm{s}}$ modulus of elasticity of reinforcing steel

$E_{s h}$ strain hardening modulus of reinforcing steel

$f_{\mathfrak{c}}^{\prime} \quad$ cylinder compressive strength of concrete

$f_{i}^{\prime} \quad$ tensile strength of concrete

$f_{y} \quad$ yield strength of reinforcing steel

$f_{\mathrm{u}} \quad$ ultimate strength of reinforcing steel

$P_{\mathrm{r}} \quad$ restraint force at centre support

$\alpha_{c} \quad$ coefficient of thermal expansion of concrete

$\alpha_{\mathrm{s}}$ coefficient of thermal expansion of steel

$\Delta_{c} \quad$ vertical deflection at centre of slab

$\Delta T$ thermal gradient between top and bottom surfaces of slab

$\varepsilon_{c}^{\prime} \quad$ strain at peak compressive stress in concrete cylinder

$\varepsilon_{\mathrm{sh}}$ strain at which strain hardening in reinforcement begins

$\phi \quad$ reinforcing bar diameter

$\rho_{x} \quad$ reinforcement ratio in $x$-direction

$\rho_{y} \quad$ reinforcement ratio in $y$-direction

$\theta$ orientation of reinforcement grid with respect to slab sides 